Review

\title{
Duration of transurethral indwelling catheter (TIC) following vaginal prolapse surgery
}

\author{
K Sivanesan ${ }^{1}$ \\ Sri Lanka Journal of Obstetrics and Gynaecology 2012; 34: 25-26
}

Our routine clinical practice suggests that prolonged catheterization, presence of a vaginal pack as well as the use of regional/general anaesthesia are certainly important factors that limit patient mobilization, hence lengthen hospital stay following vaginal prolapse surgery. Optimal duration of TIC following pelvic floor surgery has long been a debate.

A survey of the Dutch Urogynaecological Society members ${ }^{1}$ showed $75.4 \%$ of catheters are left for more than 24 hours (mean duration was 3.7 days) after anterior repair. However, majority of vaginal packs were removed on the first postoperative day.

The optimal duration of transurethral indwelling catheter (TIC) following vaginal prolapse surgery has been investigated by the following randomized clinical trials. All the studies consistently favour placement of a transurethral catheter for short term use, thus this will consequently conclude a shorter hospital stay.
Sekhavat $\mathrm{L}$ et $a l^{2}$ compared immediate versus 24 $\mathrm{hr}$ catheter removal after an anterior repair. There was no increased rate of re-catheterization and an immediate catheter removal was associated with shorter hospital stay. A similar RCT by Glavind K et $a l^{3}$ compared the removal of pack and catheter in situ for $3 \mathrm{hrs}$ and comparatively $24 \mathrm{hrs}$. Neither increased the risk of bleeding nor the need for re-operation.

In an interesting study of fast track vaginal prolapse surgery 4 indicated that the proportion of urinary retention (defined as volume $>450 \mathrm{ml}$ in their study), was only $12.2 \%$, with a median hospital stay of $24 \mathrm{hrs}$. There was high patient satisfaction and acceptability rates with only 3 out of 40 discharged after 48 hrs. Recently, Hakvoort RA et al ${ }^{5}$ showed that out of 1037 patients undergoing vaginal prolapse surgery, only 147 (14\%) experienced abnormal post void residuals. In addition, patients preferred clean intermittent catheterisation (CIC) instead of TIC in the event of abnormal post-void residuals.

\begin{tabular}{lll}
\hline Study & Indwelling catheter duration & Outcome \\
\hline Weemhoff M (2011) & 2 days Vs 5 days & $\begin{array}{l}\text { More temporary catheter placements, less } \\
\text { UTI's and shorter hospital stay in 2 day group }\end{array}$ \\
Huang CC (2011) & 2 days Vs 3 days Vs 4 days & No difference in post-void residuals \\
Hakvoort RA (2004) & 1 day Vs 4 days & $\begin{array}{l}4 \% \text { risk of UTI's in } 1 \text { day whereas } 40 \% \\
\text { incidence of UTI's in } 4 \text { day group }\end{array}$ \\
Glavind K (2007) & 3 hrs Vs 24 hrs & $\begin{array}{l}\text { Trend towards high bacterial count in the } \\
\text { urine in 24 hrs group }\end{array}$ \\
Kamilya G (2010) & 1 day Vs 4 days & $\begin{array}{l}\text { Lower UTI's and shorter hospital stay in } 1 \\
\text { day group }\end{array}$ \\
\hline
\end{tabular}

\footnotetext{
${ }^{1}$ Post CCT Fellow in IVF/Reproductive Medicine, Barts Centre for Reproductive Medicine, St. Bartholomew's Hospital, London, UK. 
There is emerging evidence that vaginal prolapse surgery under local anaesthesia with or without sedation is feasible. Even procedures such as vaginal para-vaginal repairs and vaginal uterosacral ligament suspensions have been carried out under local anaesthesia with high patient satisfaction rates ${ }^{6,7}$. Duration of the surgery does not seem to be a limiting factor. Recently, Hill N et al described their experience of local anaesthesia with conscious sedation with ramifentanyl in relation to pelvic floor repairs ${ }^{8}$. Authors were able to discharge $95 \%$ of patients six hours post-surgery without any complications. This clearly offers huge financial savings and lowers the demand for in-patient beds.

Considering the above, one should perhaps challenge our traditional ways of anaesthesia and post-operative management of vaginal surgery and should contemplate the removal of vaginal packs and catheters a few hours after surgery. If voiding difficulties are encountered, it could be managed with CIC. Careful selection of patients in addition to training of CIC prior to surgery would be of added value. In most instances, CIC could be taught by the nursing staff on the day of admission. A randomised controlled trial may be the way forward to answer the unanswered questions.

\section{References}

1. Lensen EJ, Stoutjesdijk JA, Withagen MI, Kluivers KB,
Vierhout ME. Technique of anterior colporrhaphy: a Dutch evaluation. Int Urogynecol J 2011; 22(5): 557-61.

2. Sekhavat L, Farajkhoda T, Davar R. The effect of early removal of indwelling urinary catheter on postoperative urinary complications in anterior colporrhaphy surgery. Aust N Z J Obstet Gynaecol 2008; 48(3): 348-52.

3. Glavind K, Mørup L, Madsen H, Glavind J. A prospective, randomised, controlled trial comparing 3 hour and 24 hour postoperative removal of bladder catheter and vaginal pack following vaginal prolapse surgery. Glavind K, Mørup L, Madsen H, Glavind J. Acta Obstet Gynecol Scand 2007; 86(9): $1122-5$.

4. Ottesen M, Sørensen M, Rasmussen Y, Smidt-Jensen S, Kehlet $\mathrm{H}$, Ottesen B. Fast track vaginal surgery. Acta Obstet Gynecol Scand 2002; 81(2): 138-46.

5. Hakvoort RA, Nieuwkerk PT, Burger MP, Emanuel MH, Roovers JP. Patient preferences for clean intermittent catheterisation and transurethral indwelling catheterisation for treatment of abnormal post-void residual bladder volume after vaginal prolapse surgery. BJOG 2011; 118(11): 1324-8.

6. Buchsbaum GM, Albushies DT, Schoenecker E, Duecy EE, Glantz JC. Local anaesthesia with sedation for vaginal reconstructive surgery. Int Urogynecol J Pelvic Floor Dysfunct 2006; 17(3): 211-4.

7. Buchsbaum GM, Duecy EE. Local anesthesia with sedation for transvaginal correction of advanced genital prolapse. Am J Obstet Gynecol 2005; 193(6): 2173-6.

8. Hill N, Gupta A, Zakaryan A, Morey R. The success of 6 hour hospital discharge on patients having vaginal repair operations using a new conscious sedation technique. Obstet Gynaecol 2011; 31(2): 149-51. 